\title{
Correspondence
}

\section{Grow your own: strategies to develop anesthesia researchers}

To the Editor:

How do we encourage bright, inquisitive residents to consider career paths in anesthesia research? Evidence would suggest that research in anesthesia is on the decline. The number of grants awarded by national funding agencies to departments of anesthesia is low compared to other specialties. ${ }^{1}$ To date, only one anesthesia resident in Canada has completed the Clinical Investigator Program (CIP) of the Royal College of Physicians and Surgeons. To encourage resident participation in research, two initiatives were undertaken at the Department of Anesthesia, University of Toronto.

A Research Orientation Day was established for first and second year anesthesia residents. The objectives of the Orientation |Day were to expose trainees to the breadth of research in progress at the university, but of equal importance, to discuss career paths and lifestyles of clinician-scientists. The itinerary for the Orientation Day consisted of short presentations by established investigators followed by visits to laboratories and research institutes. Following the 2004 Research Orientation Day, an anonymous survey was performed to examine residents' attitudes towards research (Table). Fifteen of the $26(58 \%)$ participants completed the survey. While only $27 \%$ of the residents were interested in research before the orientation, $60 \%$ expressed an interest in pursuing studies after the orientation. All responders perceived the day to be of great value. The initial lack of interest in research is not surprising given the limited and sporadic exposure to investigators during clinical rotations. The Orientation Day required minimal effort to organize and introduced the idea of a research career early in the trainees' education.

The second initiative was the establishment of two positions for residency candidates committed to the CIP (www.carms.ca/jsp/program.jsp?path=../program_new/504912). Residents in this stream will complete all the rotations required by the Royal College for clinical training in anesthesia. In addition, at the end of the second year of residency, they would enroll in the CIP and concomitantly pursue a Master's or $\mathrm{PhD}$ degree. This could be in either basic and clin-
TABLE Survey results

\begin{tabular}{llll}
\hline & & $\begin{array}{l}\text { Before Research } \\
\text { Orientation Day }\end{array}$ & $\begin{array}{l}\text { After Research } \\
\text { Orientation }\end{array}$ \\
& & $(n=15)$ & $(n=15)$ \\
\hline Pursuing research & Interested & 4 & 9 \\
& Undecided & 11 & 6 \\
Pursuing graduate & Not interested & 0 & 0 \\
degree & Interested & 1 & 1 \\
(Master's or PhD) & Not interested & 10 & 8 \\
\hline
\end{tabular}

ical sciences, clinical epidemiology, medical education or health administration. Enrollment in the CIP would lengthen the residency by at least one year, but would result in dual certification as a Specialist Anesthesiologist and Clinician Investigator with the Royal College. This program is designed to prepare residents to become independent clinician-scientists.

We hope these initiatives will expand the knowledge base of the specialty and will ultimately lead to improved patient care.

Viren N. Naik MD MED FRCPC

Mark F. Levine MD FRCPC

Beverly A. Orser MD PhD FRCPC

University of Toronto, Toronto, Canada

E-mail: naikv@smh.toronto.on.ca

\section{Reference}

1 Orser BA, Miller DR. New opportunities for anesthesia research in Canada. Can J Anesth 2002; 49: 895-9.

\section{Preventing pain on injection of rocuro- nium: two doses of dexmedetomidine}

To the Editor:

Dexmedetomidine is an $\alpha_{2}$ adrenoreceptor agonist with supraspinal, spinal, and peripheral actions. Alpha 2 receptors are located on blood vessels where they inhibit norepinephrine release. ${ }^{1}$ We recently conducted a study to determine the efficacy of dexmedetomidine in decreasing pain due to injection of rocuronium. 
TABLE Distribution according to intensity of pain

\begin{tabular}{lllll}
\hline & \multicolumn{4}{c}{ Pain score } \\
& 0 & 1 & 2 & 3 \\
\hline $\begin{array}{l}\text { Group I }(n=30) \\
\text { \# }\end{array}$ & $4(13.3 \%)^{*}$ & $8(26.6 \%)$ & $10(33.3 \%)$ & $8(26.6 \%)$ \\
Group II $(n=30)$ & $5(16.6 \%)^{*}$ & $10(33.3 \%)$ & $10(33.3 \%)$ & $5(16.6 \%)$ \\
Group III $(n=30)$ & $18(60 \%)$ & $7(23.3 \%)$ & $4(13.3 \%)$ & $1(3.3 \%)$ \\
\hline
\end{tabular}

Group I (saline), Group II (dexmedetomidine $0.1 \mu \mathrm{g} \cdot \mathrm{kg}^{-1}$ ), Group III (dexmedetomidine $0.2 \mu \mathrm{g} \cdot \mathrm{kg}^{-1}$ ). ${ }^{*} P<0.001$ when compared with Group III. \#P<0.05 when compared with Group III.

Following Ethics Committee approval and written informed consent, 90 patients were randomly divided into three groups. Patients had two peripheral $i v$, with one dedicated for rocuronium. Changes in mean arterial pressure, oxygen saturation, and heart rate were measured. Patients received saline $1 \mathrm{~mL}$ (Group I; $n=$ 30), dexmedetomidine $0.1 \mu \mathrm{g} \cdot \mathrm{kg}^{-1}$ (Group II; $n=$ 30 ), dexmedetomidine $0.2 \mu \mathrm{g} \cdot \mathrm{kg}^{-1}$ (Group III; $n=$ 30 ), diluted into $1 \mathrm{~mL}$ saline. Five minutes later, a priming dose of rocuronium $0.05 \mathrm{mg} \cdot \mathrm{kg}^{-1}$ was injected over 10-15 sec. The patients were observed and asked immediately if they had pain in the arm. Three minutes later a sleep dose of thiopental and rocuronium $450 \mu \mathrm{g} \cdot \mathrm{kg}^{-1}$ iv were administered. Reactions such as discomfort and pain, withdrawal of the hand, screaming etc., after the administration of rocuronium were recorded as side effects up to $24 \mathrm{hr}$.

Demographic characteristics were similar in the three groups. The number of patients experiencing no pain were four, five, and 18 in groups I to III respectively. The distribution of pain scores, according to group, are shown in the Table. No side effects were observed.

Yoshikawa et $a l^{2}$ examined the analgesic effects of orally administered clonidine on pain induced by injection of propofol. They found that with injection of propofol, pain was significantly lower with oral clonidine $\left(5.5 \mu \mathrm{g} \cdot \mathrm{kg}^{-1}\right)$. Dexmedetomidine is approximately eight times more $\alpha_{2}$ selective than clonidine. ${ }^{1}$ The mechanisms of the peripheral analgesic effect of dexmedetomidine have not yet been clearly elucidated. However, there are studies suggesting a novel role for inwardly rectifying hyperpolarization-activated conductances in peripherally mediated antinociception. ${ }^{3}$ Clonidine inhibits noradrenaline release at terminal nerve fibre endings, inducing analgesia when administered at peripheral sites, producing analgesia at intra-articular application. ${ }^{4}$ Peripheral antinociception produced by clonidine-like drugs, mediated local release of encephalin-like substances is also possible. ${ }^{5}$

While the mechanism remains uncertain, we conclude that dexmedetomidine $0.2 \mu \mathrm{g} \cdot \mathrm{kg}^{-1}$ may be useful in prevention of rocuronium injection pain.

Dilek Memis MD

Alparslan Turan MD

Gaye Kaya MD

Beyhan Karamanlioglu MD

Sermin Seker MD

Trakya University Medical Faculty, Edirne, Turkey

E-mail: dilmemis@mynet.com

\section{References}

1 Kamibayashi T, Maze M. Clinical uses of alpha 2adrenergic agonists. Anesthesiology 2000; 93: 1345-9.

2 Yoshikawa T, Wajima Z, Ogura A, Inoue T, Ogawa R. Orally administered clonidine significantly reduces pain during injection of propofol. Br J Anaesth 2001; 86: 874-6.

3 Maze M, Regan JW. Role of signal transduction in anesthetic action. Alpha 2 adrenergic agonists. Ann N Y Acad Sci 1991; 625: 409-22.

4 Gentili M, Juhel A, Bonnet F. Peripheral analgesic effect of intra-articular clonidine. Pain 1996; 64: 593-6.

5 Dalle C, Schneider M, Clergue F, Bretton C, Jirounek P. Inhibition of the $\mathrm{I}(\mathrm{h})$ current in isolated peripheral nerve: a novel mode of peripheral antinociception? Muscle Nerve 2001; 24: 254-61.

\section{Percutaneous transhepatic biliary dilatation under thoracic epidural analgesia in a patient with a recent myocardial infarction}

To the Editor:

Percutaneous transhepatic biliary drainage (PTBD) is one of the non-surgical modalities for treatment of obstructive jaundice. ${ }^{1}$ Dilatation of the biliary tracts is extremely painful and may be repeated a number of times over a few days. ${ }^{2}$ PTBD is generally performed under local anesthesia with sedation or general anesthesia. Epidural analgesia has been proposed as a method of choice for PTBD. ${ }^{2}$ We report the case of a 71-yr-old male, hypertensive patient, with a history of coronary artery disease and chest pain for the last 15 to $16 \mathrm{yr}$; progressive, painless jaundice for the last 45 days; and myocardial infarction during endoscopic retrograde cholangio pancreaticography 15 days earlier. 